\title{
Local Biomass Processing is Practical for Facilitating Fermentation to Bioethanol
}

\author{
John J. Savarese ${ }^{*}$
}

MobinolFuel Institute, 119 Hunt Club Dr., Collegeville, PA 19426, USA

\begin{abstract}
Local processing of biomass prior to fermentation at another site has advantages in transportation savings and in fermentation facility operation. To evaluate the feasibility of treating biomass locally to produce fermentation ready glucose an alkali-cellulase process was evaluated at laboratory scale using $5 \mathrm{~g}$ of three types of biomass. After pretreatment with an aqueous solution of $\mathrm{NaOH}\left(0.5 \% \mathrm{w} / \mathrm{v}, 20 \% \mathrm{w} / \mathrm{w}\right.$-biomass), $\mathrm{T}=100^{\circ} \mathrm{C} \times 12 \mathrm{~h}$, corn stover and wheat straw were shown to undergo cellulase hydrolysis to glucose; however, pine chips were not as susceptible. Commercially available cellulase was capable of producing glucose within three hours from corn stover and wheat straw. The $\mathrm{NaOH}$ pretreated biomass was mixed with enzymes in a small volume $(50 \mathrm{~mL})$ to conserve water. However, glucose inhibition of cellulase appeared to limit hydrolysis. Volume expansion by ten-fold dilution $(500 \mathrm{~mL})$ resulted in rapid release of glucose presumably by decreasing end product inhibition. Application at a commercial level will require increased water management. The resulting glucose solution could be concentrated by thermal or membrane technology for delivery to grain fermenting facilities to be used without further processing. Solids remaining after enzyme hydrolysis can be recycled locally to produce additional glucose. Scale-up of this alkali-cellulase process for local application appears feasible given the materials and conditions evaluated in this study. Local treatment of biomass using the alkalicellulase process to produce glucose to be transported to existing grain fermenting facilities is a novel approach based on reliable technology and has been demonstrated at laboratory scale.
\end{abstract}

Keywords: Biomass, alkali, cellulase, alkali-cellulase, pretreatment, bioethanol.

\section{INTRODUCTION}

Enzyme hydrolysis of cellulosic biomass as a renewable energy source to produce glucose for fermentation to bioethanol, that is, ethanol for fuel or conversion to other products is an approach that has received much attention worldwide [1]. During the last quarter century the potential of cellulosic biomass rather than petroleum as a source of liquid fuel has sparked research into cost-effective techniques for converting cellulose to ethanol [2]. Attempts to find economies in biomass conversion to fuel ethanol span decades and early on included novel techniques such as combined saccharification and fermentation [3]. Efforts to further consolidate process steps continue to be explored; for example, consolidated bioprocessing in which cellulase production, cellulose hydrolysis, and fermentation are combined has been evaluated [4]. However, even with progress challenges remain including biomass sourcing, biomass pretreatment, cellulase efficiency, and fermentation processes [5].

While the technology is feasible, delivering biomass to the conversion facility is now recognized as a major roadblock due to transportation cost and lack of infrastructure [6, 7]. One approach to offset biomass transportation difficulty is to pretreat biomass locally where it is produced, that is, near the growing site.

*Address correspondence to this author at the MobinolFuel Institute, 119 Hunt Club Dr., Collegeville, PA 19426, USA; Tel: +484-831-5749;

E-mail: savaresephdmd@mobinolfuel.com
On-farm acid pretreatment with anaerobic storage has been shown to enhance subsequent combined saccharification and fermentation to ethanol although modestly [8]. Microbiologic treatment of sorghum during harvesting and anaerobic storage has also shown promise [9]. Various other methods of biomass pretreatment have been shown to allow cellulases to hydrolyze cellulose more effectively [10].

Most pretreatments utilize severe, inconvenient, or expensive applications involving high temperature, high pressures, and corrosive chemicals [11]. Most of these approaches are not practical for local use. However, alkali pretreatment has shown promise; for example, $2 \% \mathrm{NaOH}$ for $60 \mathrm{~min}$ at $121^{\circ} \mathrm{C} / 15 \mathrm{psi}$ is effective in removing lignin from pretreated solids while maintaining a high level of glucan [12]. This work also demonstrated that $\mathrm{NaOH}$ was more effective than sulfuric acid in removing lignin from biomass (cotton stalks) and rendering the pretreatment solids more susceptible to cellulose hydrolysis. Recently $2 \%(\mathrm{w} / \mathrm{v})$ $\mathrm{NaOH}$ at $50^{\circ} \mathrm{C}$ for $96 \mathrm{~h}$ was shown to be effective in rendering switchgrass susceptible to enzyme hydrolysis [13]. They also reported that at $0.10 \mathrm{~g} / \mathrm{g}$ switchgrass, calcium hydroxide at $50^{\circ} \mathrm{C}$ for $24 \mathrm{~h}$ was an effective pretreatment [14]. Even shorter times have been reported effective as pretreatment of wheat straw, $2 \% \mathrm{NaOH}$ at $60^{\circ} \mathrm{C}$ for $90 \mathrm{~min}$ [15]. These results support the feasibility of alkali-cellulase processing under conditions achievable near the growing site or at regional centers. 
The work reported here examined alkali-cellulase processing at laboratory scale using conditions that could be scaled locally for large quantity use. Pretreatment of biomass with $\mathrm{NaOH}$ at a practical temperature and for a reasonable duration was explored. The alkali treated biomass was then subjected to hydrolysis with commercially available enzymes. This process was evaluated for its potential to produce glucose locally near growing sites for transport to fermentation facilities in a ready to use state.

\section{MATERIALS AND METHODS}

\subsection{Biomass}

Biomass consisted of corn stover, wheat straw, and pine chips that were harvested locally and shredded coarsely with an electric garden shredder (McCulloch Model MCS1400). To accommodate laboratory glassware the shredded material was further comminuted with a kitchen blender to centimeter size particles Five grams of air dried biomass were used in all experiments and results are presented per $5 \mathrm{~g}$ corn stover (CS), wheat straw (WS), or pine chips (PC).

\subsection{Experimental Conditions}

Work was done at laboratory scale that could reasonably be scaled to pilot operation using readily available materials and equipment. For alkali pretreatment $5 \mathrm{~g}$ of biomass were suspended in 200 $\mathrm{mL}$ of tap water in $500 \mathrm{~mL}$ Erlenmeyer flasks. $1 \mathrm{~g}$ of $\mathrm{NaOH}$ per $5 \mathrm{~g}$ of corn stover and wheat straw was chosen based on supporting literature [12, 13]. Given the recalcitrance of woody biomass $4 \mathrm{~g}$ of $\mathrm{NaOH}$ were used for each $5 \mathrm{~g}$ of pine chips [14]. Alkali pretreatment was conducted at $100^{\circ} \mathrm{C}$ (boiling) since even mild temperatures have proven effective with lime pretreatment of switchgrass [15]. Thermal mixing at boiling was the only agitation. Flasks were heated for twelve hours; however, shorter exposure to alkali might be possible [16]. After heating, solids were separated using a $1 \mathrm{~mm}$ wire mesh. Solids were washed twice with $100 \mathrm{~mL}$ of $30 \mathrm{mM}$ citrate buffer $\mathrm{pH} 4.5$ and the wash liquid drained. Solids were then suspended in 50 $\mathrm{ml}$ of citrate buffer $\mathrm{pH} 4.5$ and enzymes added by pipette.

\subsection{Enzymes}

Cellulose hydrolyzing enzymes supplied by Genencor were Accellerase 1500, Accellerase XC, and Accellerase $X Y$. Accellerase 1500 is a cellulase composed of endoglucanase (2200-2800 CMC U/g) and beta-glucosidase (450-775 pNPG U/g). Accellerase $X C$ is composed of endoglucanase (1000$1400 \mathrm{CMC} \mathrm{U} / \mathrm{g}$ ) and a xylanase (2500-3800 ABXU/g). Accellerase $X Y$ is xylanase $(20,000-30,000 \mathrm{ABXU} / \mathrm{g})$. Xylanase has been found to augment the activity of cellulases [17]. Amounts of enzymes used were based on the product data sheet. Enzymatic hydrolysis was done at $60^{\circ} \mathrm{C}$ and $\mathrm{pH}$ 4.5. Gentle agitation was provided with magnetic stirring bars at lowest setting. At scale-up minimal mixing or no mixing might be possible [18].

\subsection{Glucose Determination}

Glucose was measured with a glucose meter using glucose oxidase assay strips (Reveal meter and strips). Validation with standard glucose solutions done in citrate buffer $\mathrm{pH} 4.5$ at $40^{\circ} \mathrm{C}$ demonstrated the accuracy, precision, and reliability of the method. Samples reading LO contained less than $20 \mathrm{mg} / \mathrm{dL}$ and were considered undetectable in this study. Samples reading $\mathrm{HI}$, that is, above $600 \mathrm{mg} / \mathrm{dL}$ were diluted and rerun. Often Nelson-Somogyi (NS) and 3,5dinitrosalicylic acid (DNS) assays are used to determine reducing sugars such as glucose. These methods were not used since both assays have been found to provide substantially different results when used to determine cellulase activities [19]. HPLC avoids this problem but is not suited for immediate determination of glucose levels as might be done locally near a growing site.

A glass thermometer was dipped into the liquid to be assayed. When $T=40^{\circ} \mathrm{C}$ the tip was touched to the assay strip. This method requires a drop or less of sample and is specific for glucose. It does not test for xylose or glucan polymers that may be released into the liquid phase by enzymatic hydrolysis. Therefore, the glucose reported here underestimates the total glucan content including cellobiose potentially available for fermentation.

\section{RESULTS AND CONCLUSION}

\section{1. $\mathrm{NaOH}$ Pretreatment}

CS, WS, and PC were pretreated with $\mathrm{NaOH}$ as described above. The solution darkened quickly due to the release of lignin. Xylose, other non-glucose monomers, and carbohydrate polymers released into the alkaline solution were not measured. Glucose released into the $\mathrm{NaOH}$ solution is shown in Table 1. 
Table 1: Total Glucose (Mean and Standard Deviation from four Experiments) in $200 \mathrm{~mL}$ Liquid Above NaOH Treated Biomass for 12 hours at $\mathrm{T}=100^{\circ} \mathrm{C}$

\begin{tabular}{|c|c|c|c|}
\hline & $\mathbf{1 ~ g ~ N a O H} / \mathbf{5} \mathbf{~ C S}$ & $\mathbf{1 ~ g ~ N a O H} / \mathbf{~ g ~ W S}$ & $\mathbf{4} \mathbf{~ g ~ N a O H} / \mathbf{5}$ PC \\
\hline \hline Mean & $200 \mathrm{mg}$ & $252 \mathrm{mg}$ & $1105 \mathrm{mg}$ \\
\hline SD & $60 \mathrm{mg}$ & $16 \mathrm{mg}$ & $143 \mathrm{mg}$ \\
\hline
\end{tabular}

The release of more glucose from pine chips is probably due to the greater amount of $\mathrm{NaOH}$ used in pretreatment. Glucose in the alkaline solution will be lost from the amount produced by enzymatic hydrolysis of the remaining solids but might be captured after processing of the spent solution. It is anticipated that the $\mathrm{NaOH}$ solution could be reused for additional pretreatments until the alkalinity is reduced to below effective concentration. The residual liquid could then be neutralized with acid and used for irrigation or processed to recover lignin and other organic components including glucose.

\subsection{Enzyme Hydrolysis and Volume Expansion}

The release of glucose is shown in Figure 1 at one hour after adding enzymes (1 $\mathrm{h} 50 \mathrm{~mL})$. This demonstrates the binding of cellulase and xylanase to the alkali treated solids in $50 \mathrm{~mL}$ buffer. However, the amount of glucose produced was small and only slightly higher than that for biomass not treated with $\mathrm{NaOH}$. While using small volumes for enzyme hydrolysis has the advantage of less water use, it is probable that enzyme inhibition by glucose reduces its release since it is known that glucose can inhibit cellulase activity [20]. This was tested by diluting the 50 $\mathrm{mL}$ with citrate buffer by ten-fold, that is, by a rapid volume expansion.

Figure 1 shows that volume expansion does have a marked effect on the release of glucose presumably by decreasing the concentration of glucose and possibly other products thereby decreasing cellulase inhibition. At the time of dilution to $500 \mathrm{~mL}$, that is, at $0 \mathrm{~h} 500 \mathrm{~mL}$, the amount of glucose produced from CS was 3.75 times that produced in $50 \mathrm{~mL}$ after one hour exposure to enzymes. Comparing the amount of glucose released at $1 \mathrm{~h} 50 \mathrm{~mL}$ with that after volume expansion for one hour, that is, at $1 \mathrm{~h} 500 \mathrm{~mL}$, demonstrated a 5.75 times greater release of glucose from CS.

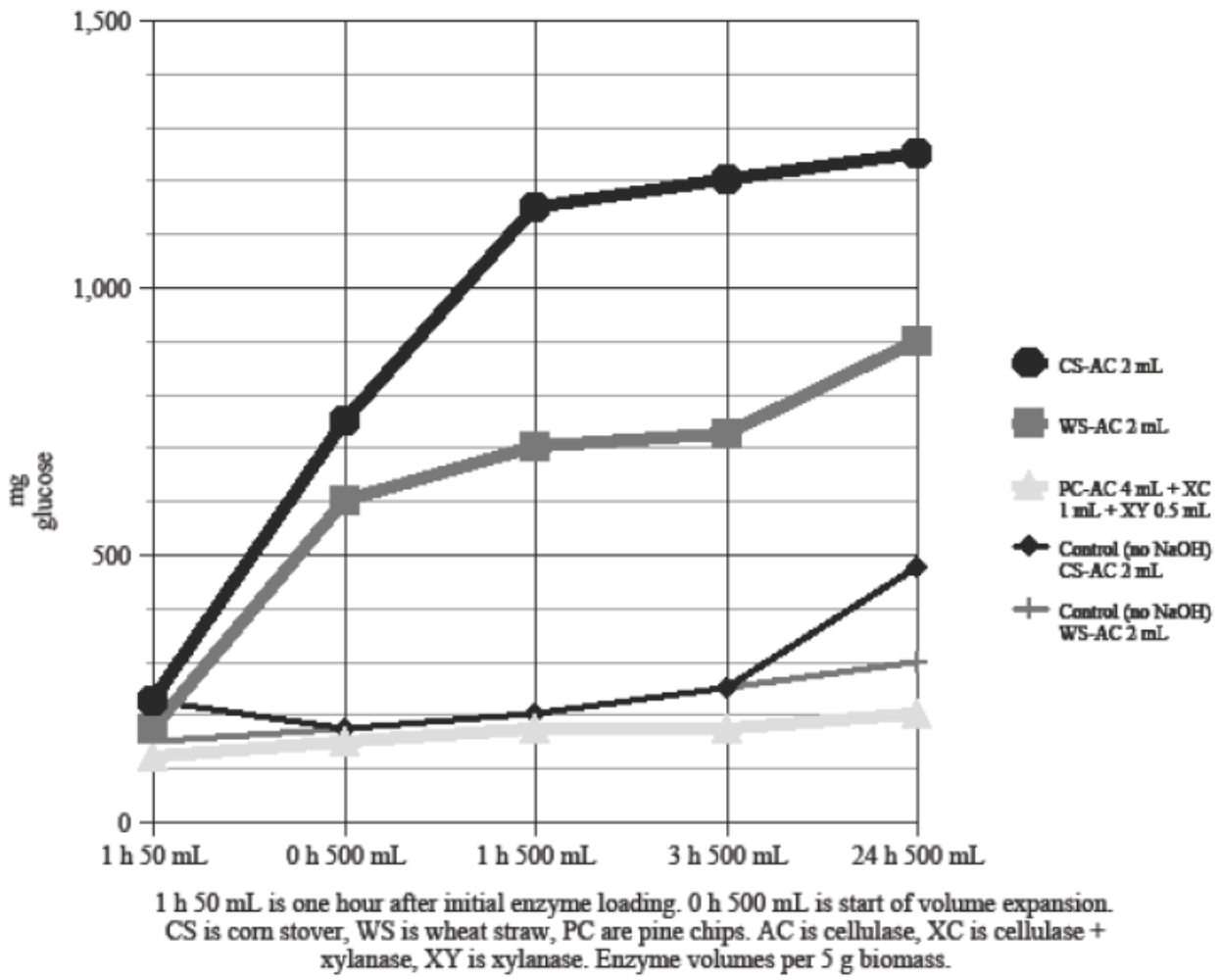

Figure 1: Time and volume of enzyme treatment. Glucose as mean of three experiments from 5 grams each of three types of $\mathrm{NaOH}$ treated biomass after one hour exposure in $50 \mathrm{~mL}$ citrate buffer, and at the time of dilution and thereafter. 


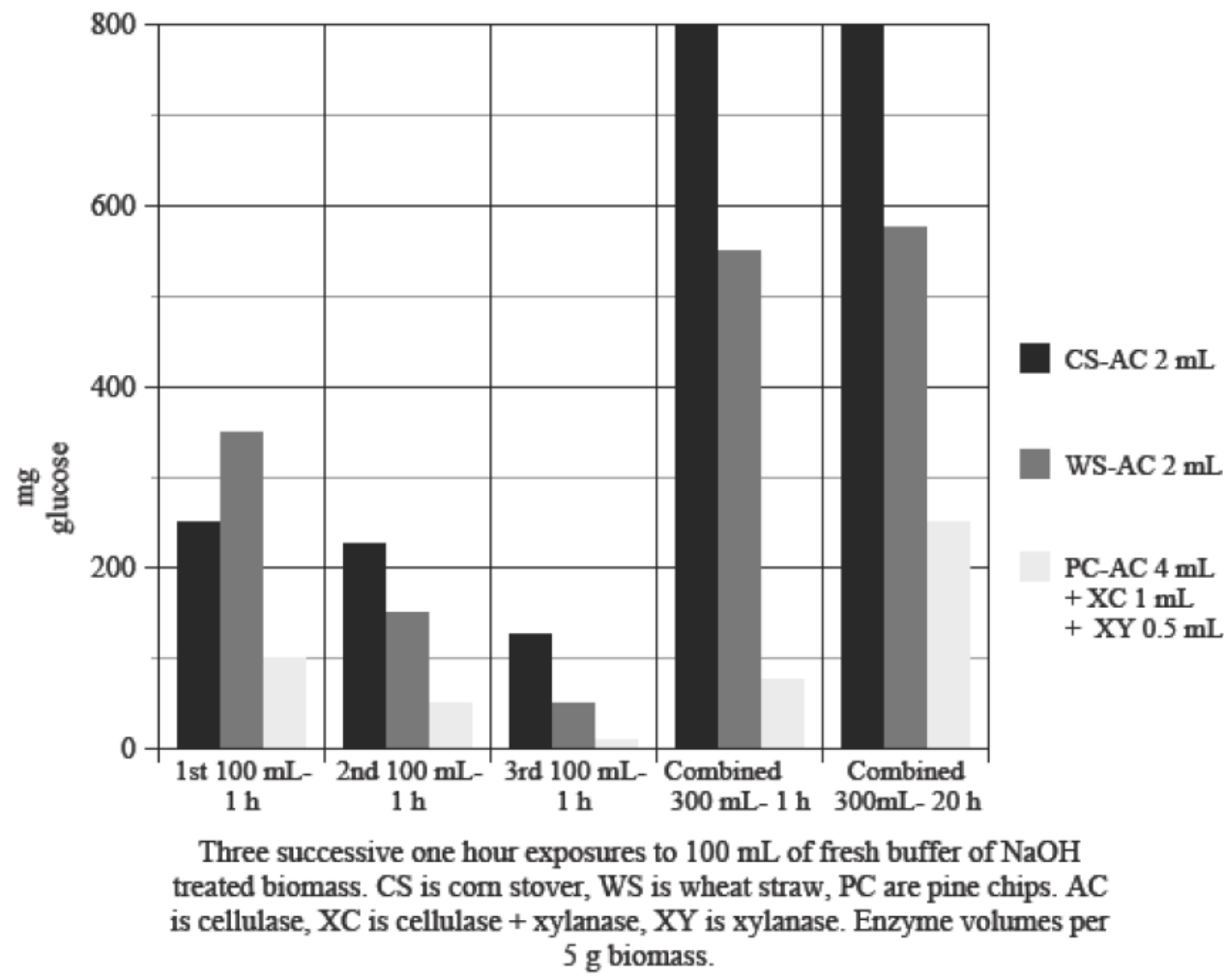

Figure 2: Effect on glucose production of successive exposures to fresh buffer. Glucose as a mean of three experiments from 5 $\mathrm{g}$ each of three types of $\mathrm{NaOH}$ treated biomass after initial enzyme loading following buffer changes and combination.

Woody biomass may not be suitable for this alkalicellulase treatment since glucose yields are minimal for $\mathrm{PC}$ as shown in Figure $\mathbf{1}$ in spite of high enzyme loading that included cellulase and xylanase. The effect of bypassing $\mathrm{NaOH}$ pretreatment is shown by the CS and WS control groups. Little glucose was produced with cellulase treatment when the biomass was not pretreated with $\mathrm{NaOH}$. Glucose produced from PC without $\mathrm{NaOH}$ pretreatment was undetectable and not shown in the figure. Also, CS (5 g) when pretreated with $2 \mathrm{~g} \mathrm{NaOH}$ under the same experimental conditions but without enzyme treatment did not produce glucose. Since corn stover was the most susceptible to hydrolysis it is reasonable to assume wheat straw and pine chips would also not produce glucose without enzymes.

Corn stover contains approximately $40 \%$ cellulose and wheat straw $35 \%$ cellulose [21]. In this study glucose yields at $24 \mathrm{~h}$ of enzyme hydrolysis were approximately $60 \%$ and $50 \%$ of theoretical for CS and WS, respectively. This does not include glucose lost by alkali pretreatment or that remaining in the residual solids. Also, not included are cellobiose or glucans released by enzyme hydrolysis. Important to commercial operation, most initial enzyme activity occurred within three hours. Reports show an initial burst of cellulase activity that achieves $50 \%$ conversion of cellulose within 24 hours [22]. The less time required for enzyme hydrolysis the greater will be the economic feasibility of the alkali-cellulase process. However, this gain will be mitigated by the need for greater use of water.

A strategy to minimize water use would be to remove glucose by draining smaller volumes of liquid and replacing with fresh buffer. Results of this approach are shown in Figure 2. Following $\mathrm{NaOH}$ treatment and washing, enzymes were added to the solids in $100 \mathrm{~mL}$ of buffer. At one hour of enzyme treatment glucose was measured $\left(1^{\text {st }} 100 \mathrm{~mL}-1 \mathrm{~h}\right)$ and the liquid replaced with another $100 \mathrm{~mL}$ of buffer. This procedure was repeated in another hour $\left(2^{\text {nd }} 100 \mathrm{~mL}-1\right.$ h) and then for a third time $\left(3^{\text {rd }} 100 \mathrm{~mL}-1 \mathrm{~h}\right)$.

As expected, replacement of the $100 \mathrm{~mL}$ aliquots resulted in decreasing yields of glucose. After the third aliquot was tested for glucose all three $100 \mathrm{~mL}$ volumes were combined along with the remaining solids. One hour later glucose was measured (Combined $300 \mathrm{~mL}-1 \mathrm{~h}$ ) and at 20 hours (Combined $300 \mathrm{~mL}-20 \mathrm{~h}$ ). The combined volumes had more glucose than the sum of the three volumes since enzyme hydrolysis continued during the hour following 


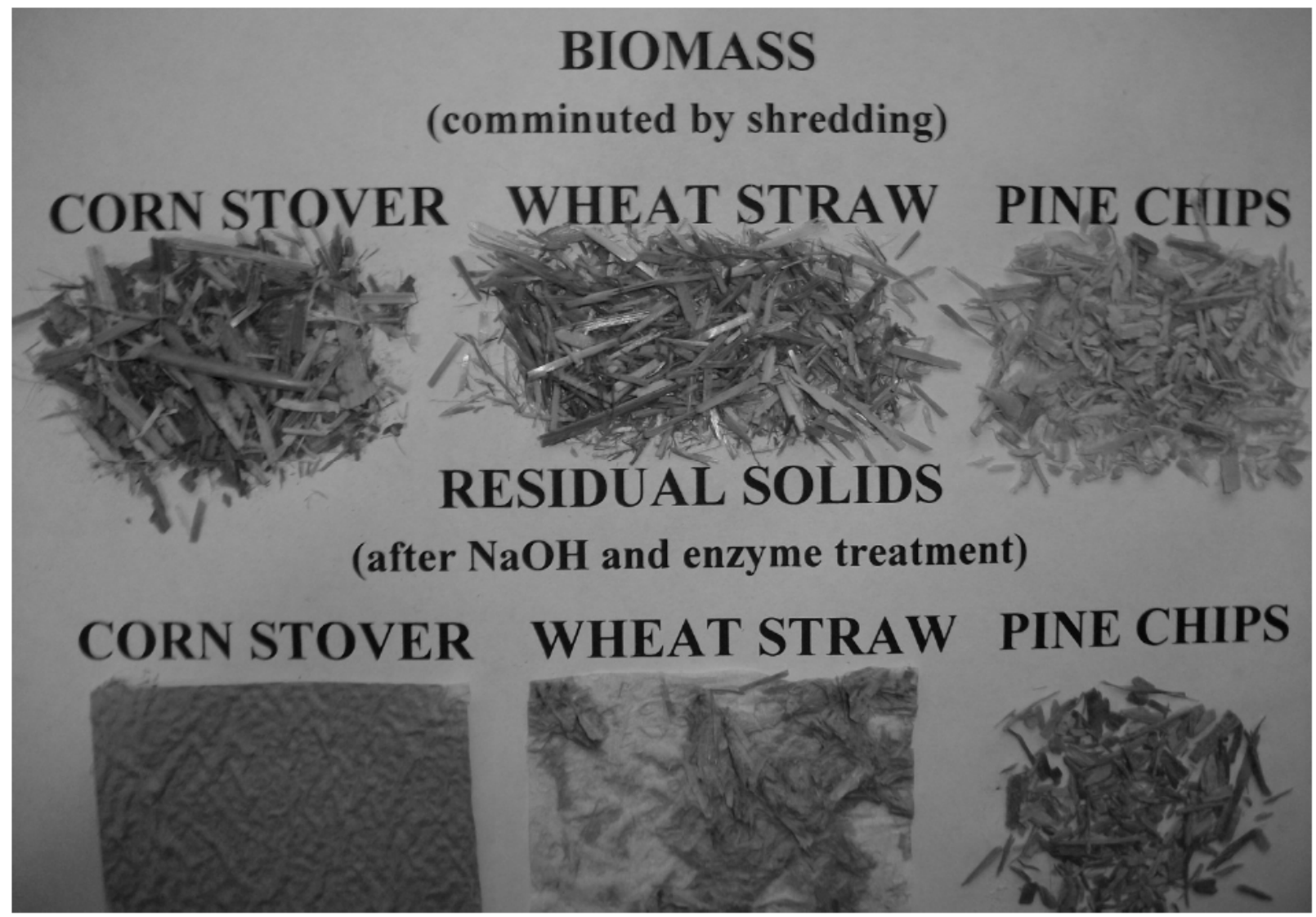

Figure 3: Original three types of biomass before processing and residual solids remaining after processing.

combination and this is the value given (Combined 300- $1 \mathrm{~h}$ ) and not that when the aliquots were initially combined. The combined volumes resulted in release of more glucose from corn stover and wheat straw after one hour and from all three biomasses at 20 hours. However, if there is proportionality, calculation shows that the concentration of glucose in the $300 \mathrm{~mL}$ volume was the same as in the $500 \mathrm{~mL}$ shown in Figure 1. Therefore, this approach does not appear to provide an advantage over conducting the enzymatic hydrolysis in an increased fixed volume, that is, with volume expansion with buffer.

These results support the feasibility of an alkalicellulase protocol that can produce glucose using readily available materials over reasonable processing time and with equipment not requiring pressure, high temperatures, or having concerns of corrosion. However, the production of large volumes of dilute glucose concentration probably requires a concentration procedure. Concentrating sugars with membranes is a common procedure in the food industry [23]. Thermal concentration is an alternative that has the advantage of producing steam for heating other stages of the process.
The lignin containing alkali solution can be used to treat additional batches of biomass until its effect on biomass cellulose decreases. The spent alkali solution when neutralized would be suitable for irrigation or shipped for processing to recover dissolved organics particularly lignin. The residual solids could be recycled through enzyme hydrolysis for additional glucose.

\subsection{Recycling Residual Solids}

Since residual solids may still contain hydrolyzable cellulose, further enzyme treatment could produce additional glucose. Figure $\mathbf{3}$ shows dried residual solids following alkali-cellulase treatment.

Corn stover appeared most susceptible to the alkalicellulase treatment as demonstrated by the resulting homogeneous dried paste. Wheat straw was less susceptible and pine chips appeared to undergo little change.

Residual solids were suspended in buffer and enzymes added. Results shown in Table 2 indicate that additional glucose can be obtained especially from corn stover residual solids although higher levels of enzymes were needed. 
Table 2: Glucose in Five Experiments Using Additional Enzyme Treatment on Residual Solids (RS) Obtained After $\mathrm{NaOH}$ and Enzyme Treatment of Three Types of Biomass

\begin{tabular}{|c|c|c|c|c|c|}
\hline \multirow[t]{2}{*}{ Residual Solids(RS) } & \multirow{2}{*}{$\begin{array}{l}\text { \%RS from } \\
\text { starting } 5 \mathrm{~g} \\
\text { biomass }\end{array}$} & \multirow[t]{2}{*}{$\begin{array}{c}\text { Enzyme treatment } \\
\text { (added to starting } 100 \mathrm{~mL} \text { ) }\end{array}$} & \multicolumn{3}{|c|}{$\begin{array}{l}\text { Glucose } \mathrm{mg} / \mathrm{g} \mathrm{RS} \\
\text { [then buffer added to reach } 500 \mathrm{~mL} \text { ] }\end{array}$} \\
\hline & & & $\begin{array}{c}0 \mathrm{~h} \\
(100 \mathrm{~mL})\end{array}$ & $\begin{array}{c}8 \mathrm{~h} \\
(100 \mathrm{~mL})\end{array}$ & $\begin{array}{c}24 \mathrm{~h} \\
(500 \mathrm{~mL})\end{array}$ \\
\hline 1) $\mathrm{CS}$ & $22 \%$ & $2 \mathrm{~mL} \mathrm{AC^{a }}$ & 27 & 61 & $\mathrm{LO}^{d}$ \\
\hline 2) WS & $36 \%$ & $2 \mathrm{~mL} \mathrm{AC}$ & 22 & 49 & LO \\
\hline 4) CS & $10 \%$ & $\begin{array}{l}4 \mathrm{~mL} \mathrm{AC+} \\
1 \mathrm{mLXC}+ \\
0.5 \mathrm{mLXY}\end{array}$ & 83 & 167 & 375 \\
\hline 5) WS & $34 \%$ & $\begin{array}{l}4 \mathrm{~mL} \mathrm{AC+} \\
1 \mathrm{~mL} X \mathrm{C}_{+} \\
0.5 \mathrm{~mL} X Y\end{array}$ & 30 & 40 & LO \\
\hline
\end{tabular}

${ }^{*} 100 \mathrm{~mL}$ rather than $50 \mathrm{~mL}$ to enhance glucose release; ${ }^{\mathrm{a}} \mathrm{AC}=$ cellulase $;{ }^{b} \mathrm{XC}=$ xylanse + cellulase; ${ }^{\mathrm{C}} \mathrm{XY}=\mathrm{xylanase} ;{ }^{\mathrm{d}} \mathrm{LO}=$ not detected presumably due to dilution.

It appears that recycling the residual solids provides additional glucose and should enhance economic feasibility.

\section{CONCLUSION}

Pretreatment with $\mathrm{NaOH}\left(0.5 \% \mathrm{w} / \mathrm{v}-\mathrm{H}_{2} \mathrm{O}, 20 \% \mathrm{w} / \mathrm{w}\right.$ biomass) at $100^{\circ} \mathrm{C}$ for $12 \mathrm{~h}$ rendered biomass susceptible to enzyme hydrolysis. Cellulase hydrolysis for three hours or less was sufficient to produce glucose. Volume expansion substantially enhanced glucose production. Repeated processing of residual solids can produce additional glucose that can maximize yields. Allkali-cellulase processing can be done locally or at regional depots. The concept of regional biomass processing depots for initial pretreatment is currently being explored [24]. Concentrating the resulting glucose solution will be necessary to allow economical transport. Local treatment of biomass using the alkali-cellulase process to produce glucose for ethanol production at existing grain fermenting facilities is a novel approach that has been demonstrated at laboratory scale using in this study using materials and methods that can be easily scaled-up.

\section{REFERENCES}

[1] Sarkar N, Ghosh SK, Bannerjee S, Aikat K. Bioethanol production from agricultural waste: an overview. Renew Energy 2012; 37: 19-27. http://dx.doi.org/10.1016/j.renene.2011.06.045

[2] Lynd LR, Cushman JH, Nichols RJ, Wyman CE. Fuel ethanol from cellulosic biomass. Science 1991; 251: 1318-23. http://dx.doi.org/10.1126/science.251.4999.1318
[3] Savarese JJ, Young SD. Combined enzyme hydrolysis of cellulose and yeast fermentation. Biotechnol Bioeng 1978; 20: 1291-93.

http://dx.doi.org/10.1002/bit.260200814

[4] Lynd LR, van Zyl WH, McBride JE, Laser M. Consolidated bioprocessing of cellulosic biomass: an update. Curr Opin Biotechnol 2005; 16: 577-83. http://dx.doi.org/10.1016/i.copbio.2005.08.009

[5] Banerjee S, Mudliar S, Sen R, Giri B, Satpute D, Chakrabarti T, Pandey RA. Commercializing lignocellulosic bioethanol: technology bottlenecks and possible remedies. Biofuels Bioprod Bioref 2010; 4: 77-93. http://dx.doi.org/10.1002/bbb.188

[6] Hess JR, Wright CT, Kenney KL. Cellulosic biomass feedstocks and logistics for ethanol production. Biofuels Bioprod Bioref 2007; 1: 181-90.

http://dx.doi.org/10.1002/bbb.26

[7] Richard TL. Challenges in scaling up biofuels infrastructure Science 2010; 329: 793-96.

\section{http://dx.doi.org/10.1126/science.1189139}

[8] Digman MF, Shinners KJ, Muck RE, Dien BS. Full-scale onfarm pretreatment of perennial grasses with dilute acid for fuel ethanol production. Bioenerg Res 2010; 3: 335-41.

[9] Williams SD, Shinners KJ. Farm-scale anaerobic storage and aerobic stability of high dry matter sorghum as a biomass feedstock. Biomass Bioenerg 2012; 46: 309-16.

http://dx.doi.org/10.1016/j.biombioe.2012.08.010

[10] Wyman CE, Dale BE, Elander RT, Holtzapple M, Ladisch MR, Lee YY. Comparative sugar recovery data from laboratory scale application of leading pretreatment technologies to corn stover. Bioresour Technol 2005; 96 2026-32.

http://dx.doi.org/10.1016/j.biortech.2005.01.018

[11] Wyman CE, Balan V, Dale BE, Elander RT, Falls M, Hames $\mathrm{B}$, et al. Comparative data on effects of leading pretreatments and enzyme loadings and formulations on sugar yields from different switchgrass sources. Bioresour Technol 2011; 102: 11052-62.

http://dx.doi.org/10.1016/j.biortech.2011.06.069

[12] Silverstein RA, Chen $Y$, Sharma-Shivappa RR, Boyette MD, Osborne J. A comparison of chemical pretreatment methods for improving saccharification of cotton stalks. Bioresour Technol 2007 98: 3000-11. http://dx.doi.org/10.1016/j.biortech.2006.10.022 
[13] Xu J, Cheng JJ, Sharma-Shivappa RR, Burns JC. Sodium hydroxide pretreatment of switchgrass for ethanol production. Energy Fuels 2010; 24: 2113-19. http://dx.doi.org/10.1021/ef9014718

[14] Xu J, Cheng JJ, Sharma-Shivappa RR, Burns JC. Lime pretreatment of switchgrass at mild temperatures for ethanol production. Bioresour Technol 2010; 101: 2900-903. http://dx.doi.org/10.1016/j.biortech.2009.12.015

[15] Mclntosh S, Vancov T. Optimisation of dilute alkaline pretreatment for enzymatic saccharification of wheat straw. Biomass Bioenerg 2011; 35: 3094-103. http://dx.doi.org/10.1016/j.biombioe.2011.04.018

[16] Zhu JY, Pan X, Zalesny RS. Pretreatment of woody biomass for biofuel production: energy efficiency, technologies, and recalcitrance. Appl Microbiol Bioteechnol 2010; 87: 847-857. http://dx.doi.org/10.1007/s00253-010-2654-8

[17] Kumar R, Wyman CE. Effect of xylanase supplementation of cellulase on digestion of corn stover solids by leading pretreatment technologies. Bioresour Technol 2009; 100: 4203-13. http://dx.doi.org/10.1016/j.biortech.2008.11.057

[18] Taneda D, Ueno Y, Okino S. Characteristics of enzyme hydrolysis of cellulose under static condition. Bioresour Technol 2012; 121: 154-60. http://dx.doi.org/10.1016/j.biortech.2012.06.104

[19] Gusakov AV, Kondratyeva EG, Sinitsyn AP. Comparison of two methods for assessing reducing sugars in the determination of carbohydrase activities. Int $\mathrm{J}$ Anal Chem 2011; 2011: 1-4.

[20] Holtzapple M, Cognata M, Shu Y, Hendrickson C. Inhibition of Trichoderma reesei cellulase by sugars and solvents. Biotechnol Bioeng 1990; 36: 275-87.

http://dx.doi.org/10.1002/bit.260360310

[21] Walker GM. $125^{\text {th }}$ anniversary review: fuel alcohol: current production and future challenges. J Inst Brew 2011; 117: 322.

http://dx.doi.org/10.1002/j.2050-0416.2011.tb00438.x

[22] Murphy L, Cruys-Bager N, Damgaard HD, Baumann MJ, Olsen SN, Borch K, et al. Origin of initial burst in activity for Trichoderma reesei endo-glucanases hydrolyzing insoluble cellulose. J Biol Chem 2010; 287: 1252-60. http://dx.doi.org/10.1074/jbc.M111.276485

[23] Garcia-Castello EM, McCutcheon JR, Elimelech M. Performance evaluation of sucrose concentration using forward osmosis. J Memb Sci 2009; 338: 61-66. http://dx.doi.org/10.1016/j.memsci.2009.04.011

[24] Eranki PL, Bals BD, Dale BE. Advanced regional biomass processing depots: a key to the logistical challenges of the cellulosic biofuel industry. Biofuels Bioprod Bioref 2011; 5: 621-30.

http://dx.doi.org/10.1002/bbb.318 